\title{
Public relations campaign strategy PT. Pelindo 1 in socializing the Porting Business
}

\author{
Denny Wahyudi ${ }^{\text {a, },{ }^{*},}$, Abrar Adhani ${ }^{\text {b,2 }}$ \\ ${ }^{a}$ Public Relations University of Muhammadiyah Sumatera Utara \\ ${ }^{1}$ exvanzio@gmail.com*; ${ }^{2}$ abraradhani@umsu.ac.id; \\ * corresponding author
}

Article history

Received 11-12-2020

Revised 19-12-2020

Accepted 29-12-2020

Keywords

Strategy

Public Relations Campaign

Port Business

Port Visit

\begin{abstract}
PT. Pelabuhan Indonesia I (Persero) is a corporation engaged in the maritime and port sector under the auspices of the Ministry of StateOwned Enterprises (BUMN) headquartered in Belawan, North Sumatra. As a corporation, of course, a campaign is required to inform the business being run so that it is more widely known by the public. As a form of public relations campaign and an effort to socialize its business, Pelindo 1 offers Port Visit activities as a means of learning about the world of ports. This research was conducted to find out how PT Pelindo 1's Public Relations Campaign Strategy in Disseminating its Port Business through the Port Visit program. In this research, it focuses on Port Visit activities with PERHUMAS Muda Medan which was held on February 28, 2020. The type of research that the writer does is descriptive qualitative. In this study, the authors used the theory of Corporate Campaign Theory and AIDDA theory as the basis for campaign marketing. By using the direct observation method where the author participates in the concept-making process and organizing activities as well as the interview method with 5 (five) resource persons, 2 (two) of whom are the Pelindo 1 public relations team, and 3 (three) others are activity participants. The result of this research is that Pelindo 1 's PR has made the Port Visit activity a superior program and campaign tool to socialize port business to the community. This is evidenced by the fact that Port visits are registered in the company's Monthly Activity Plan (RKB) and are carried out routinely 2-3 times in a few months. Based on the results of the research, the participants who took part in the Port Visit activity admitted that the concept was not only theoretical but involved directly in the field to see the port area, as well as a fun session as an evaluation stage, making their thinking about the world of the ports and the role and function of ports change not only as a place leaning on ships but serving as a gateway to the world economy.
\end{abstract}

This is an open access article under the CC-BY-SA license.

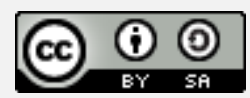

\section{Introduction}

Image, maybe that's what comes to your mind when you hear the word public relations, but it turns out that the real definition of public relations / public relations does not only discuss imaging. According to experts, until now there is no absolute meaning of the definition of PR / PR. There are many terms in the world of public relations, perhaps the image that stands out the most. It cannot be denied that public relations cannot be separated from communication activities. Apart from building the image of a public relations practitioner, he must carry out his role, namely to inform, to educate, to entertain, to influence (Watts, 2006).

In this research, it focuses on research studies based on the communication function of PT. Pelabuhan Indonesia I (Persero) or often abbreviated as Pelindo 1 is an agency that stands under the 
auspices of the Ministry of State-Owned Enterprises (BUMN) which are engaged in the port and maritime sector, of course, it cannot be separated from the active role of various company components in advancing and fostering a positive image. company in the eyes of the public. Of the several PR campaigns conducted by Pelindo 1, the focus is on the port visit program which is the flagship program of Pelindo 1, which is constantly introducing the business they run. As a form of the PR campaign, the writer is interested in researching the strategies and persuasive messages that were inserted by the PR team of Pelindo 1 in organizing a port visit in order to disseminate port business to the public. According to Harold Lasswell's model of communication, there are five elements in communication, namely "who says what to whom in which channel with what effect" or if translated into Indonesian it will read "who says what to whom in what channel with what impact". Based on the description above, the writer decided to focus this research on what message elements were conveyed and what strategies were used by the Pelindo 1 public relations team so that the message conveyed was not only accepted by the public but also influenced or even followed by the suggestions that were inserted through the message in socializing port business to the community. The purpose of this study is to provide an overview of the strategies applied by PT Pelindo 1 in socializing the port business which is the focus of research at PT Pelindo 1 Medan (Iekfe4jkf, 2018).

\section{Theorotocal Framework}

\section{1) Public Relations Campaign}

According to Glueck \& Jauch (1975) Strategy is defined as an initial plan that has been combined from an integrated work program that connects an advantageous strategic plan of a company or organization that is able to see opportunities, challenges designed to ensure that something is the target of a company in order to be achieved through the proper implementation and accounting carried out by an organization or company The campaign has been known since the 19th-century "campaign is generally exemplary persuasion in actions" which means that the campaign, in general, gives the appearance of an activity that aims to persuade and influence the starting public to persuade. Public Relations Campaign is a communication technique used by a Public Relations practitioner to achieve goals that can be seen from the vision and mission of the organization (Levin, 2014).

The Public Relations campaign aims to grow awareness of public knowledge in order to grab attention and create a positive perception of the activities of company organizations that aim to build trust and a good image of the community from intensive messaging in the ongoing communication process. In a broad sense, public relations campaigns can provide information to the public to gain understanding and motivate the public towards an activity or work program through a continuous and planned communication process and technique in order to achieve the desired publicity and positive image for the sustainability and existence of the organization (Ruslan, 2012).

\section{2) Public Relations}

Activities Public relations activities depend on the character of the organization in carrying out the vision, mission of the organization and the goals to be achieved. The wider the public component with an interest in the organization, the wider the public element will be, the more diverse and the problems will be more complex. Public relations activities include the following activities:

- Internal Relation

Internal Relations is an internal part of public relations which aims to build and maintain good and beneficial relationships between company leaders and employees or vice versa where the organization is the place to depend on its success.

- Publicity

Publicity is defined as information available from outside sources by the media because the information has news value. The method used in this publicity is a controlled method because the source of the information cannot pay the media for loading the information. 
- Advertising

Advertising is defined as a media sponsor whose identity is clear, both space and time, of information placement relating to offers and information that must be controlled in placing messages in the media (Thorson \& Rodgers, 2019).

- Press Agentry

Press Agentry is defined as news and events that are created that have news value so that attention to the public can be focused and packaged to attract public attention.

- Public Affairs

Public affairs is a special part of public relations that can build and maintain relationships with the government and local communities to influence public policy.

- Lobbying

Lobbying is part of public relations activities that aim to maintain and establish good relations with the government, especially to influence the process of drafting statutory regulations. In practice, lobbying should be based on cooperation aimed at the non-governmental public

- Issue Management

Issue Management is a proactive process to anticipate, identify, evaluate, and respond to public policy issues that can affect the organization's relationship with the public.

- Investor Relations

Relationships with investors are company activities that build beneficial and mutually beneficial relationships for both in order to maximize market value.

- Development

Development is an activity that aims to build, maintain relationships, and obtain voluntary funding and support. In essence, all public relations activities are designed to be touched by all the public in public relations activities (Kriyantono, 2015).

The concept of a corporate organization campaign is defined as a study in communication, the concept of corporate campaigns as a theoretical study in the field of communication was first introduced by Robert Heath and Richard Nelson in their book, Issues Management: Corporate Public Policy Making in an Information Society. According to Heath, this concept can be seen as the promotion of a product produced and managing issues management as shown in the chart below (Littlejohn \& Foss, 2012).

\section{Method}

The method used in this research uses qualitative methods. The goal is to find out and find actual information about what is happening and is taking place and make compensation and evaluation (Deddy Rakhmad Hidayat \& Firdaus, 2014). In research with this method, the technique is to describe, describe, and interpret an object under study so that the focus of the study is how PT Pelindo 1's public relations campaign strategy is in disseminating its port business to the public through observation and in-depth interviews with the Pelindo 1 Public Relations team.

\section{Results and Discussion}

PT. Pelabuhan Indonesia I (Persero) is a corporation that is established under the Ministry of State-Owned Enterprises (BUMN) engaged in maritime affairs. In running its business, Pelindo 1 offers several public relations programs, namely, Port Visit, Port Community, Corporate Image Index, Pelindo 1 Digital Force, and Pelindo 1 Task Force which acts as oversight of the Covid-19 case.

W: http://journal2.uad.ac.id/index.php/commicast/index | E: commicast@comm.uad.ac.id 
Public relations campaign activities carried out by Pelindo 1, especially in socializing the port business, are carried out in several ways, namely directly and indirectly. First, indirectly, is using social media such as Instagram, YouTube, and the Official Website. For direct campaigns, Pelindo 1 has a special program, namely Port Visit.

This flagship program that has been listed in the Monthly Activity Plan (RKB) is a special program where Pelindo 1 opens for anyone who wants to learn and see the port world directly. In general, this activity begins by submitting a visit request letter from prospective activity participants. This activity with the concept of material exposure and field studies was last carried out directly with the student organization, namely PERHUMAS Muda Medan on February 28, 2020.

Public relations campaign strategy of PT. Pelindo 1 in socializing activities such as Port Visit as a means of learning about the world of ports, namely the division between material exposure and field studies conducted on a scale of $30 \%-70 \%$, this field study is considered positive where this activity has succeeded in opening their minds and changing their understanding of the world of ports. From what initially only thought of a port as a place for ships to dock, as a gateway and access to the world of export and import of raw materials and daily necessities, even more so, ports are one of the supporting aspects of the country's economy.

\section{Conclusion}

PT. Pelabuhan Indonesia I (Persero) is a corporation that stands under the Ministry of StateOwned Enterprises (BUMN) which engaged in the maritime sector. In running its business, Pelindo 1 offers several public relations programs namely, Port Visit, Port Community, Corporate Image Index, Pelindo 1 Digital Force, as well Pelindo 1 Task Force which acts as oversight of cases Covid19. Public relations campaign activities conducted by Pelindo 1 especially in socializing the port business in two ways, namely direct and indirect. Not direct namely using social media such as Instagram, YouTube, and Official Website. For direct campaigns, Pelindo 1 has a special program, namely Port Visit. The flagship program already listed in this Monthly Activity Plan (RKB) is a special program where Pelindo 1 opens for anyone who wants to learn and see the port world first hand. In general, this activity starts with doing the submission of a visit request letter from prospective activity participants.

\section{Acknowledgment}

A big thanks are given to related elements such as the Communication Studies Program at the Muhammadiyah University of North Sumatra as a means of gaining knowledge. Hopefully, the Muhammadiyah University of North Sumatra will remain consistent as a pillar of higher education that can produce quality graduates. 


\section{References}

Deddy Rakhmad Hidayat, \& Firdaus, M. R. (2014). Analisis Pengaruh Kualitas Layanan, Harga, Kepercayaan, Citra Perusahaan, dan Kepuasan Pelanggan Terhadap Loyalitas Pelanggan: (Studi Pada Pelanggan Telkom Speedy Di Palangka Raya). Wawasan Manajemen.

Glueck, W. F., \& Jauch, L. R. (1975). Sources of Research Ideas among Productive Scholars. The Journal of Higher Education. https://doi.org/10.1080/00221546.1975.11780631

Iekfe4jkf, E. (2018). Profil Perusahaan.

Kriyantono, R. (2015). Public Relations and Corporate Social Responsibility in Mandatory Approach Era in Indonesia. Procedia - Social and Behavioral Sciences. https://doi.org/10.1016/j.sbspro.2015.11.041

Levin, S. A. (2014). Public goods in relation to competition, cooperation, and spite. Proceedings of the National Academy of Sciences of the United States of America. https://doi.org/10.1073/pnas.1400830111

Littlejohn, S., \& Foss, K. (2012). Encyclopedia of Communication Theory. In Encyclopedia of Communication Theory. https://doi.org/10.4135/9781412959384

Ruslan, R. (2012). Manajemen Public Relations dan Media Komunikasi: Konsepsi dan Aplikasi. In Rajawali Pers.

Thorson, E., \& Rodgers, S. (2019). Advertising. In An Integrated Approach to Communication Theory and Research, Third Edition. https://doi.org/10.4324/9780203710753-17

Watts, R. (2006). What is the role of public relation theory? Journal of Communication Management. https://doi.org/10.1108/13632540610646427 